\author{
Rafał Łatka \\ (Uniwersytet Papieski Jana Pawła II w Krakowie)
}

\title{
Krakowski etap I pielgrzymki Jana Pawła II do Ojczyzny z perspektywy władz PRL. Próba syntetycznego spojrzenia
}

\author{
The Cracow Stage of the First Pilgrimage of the Pope John Paul II \\ to the Homeland from the Point of View of the Authorities of the People's \\ Republic of Poland. An Attempt at a Synthetic View
}

\section{STRESZCZENIE}

Celem mojej analizy jest dokładne i możliwie całościowe spojrzenie na krakowski etap pierwszej wizyty Jana Pawła II do Ojczyzny, przede wszystkim z perspektywy władz komunistycznych. W artykule zwróciłem szczególną uwagę na charakter polityki władz PRL wobec wizyty Ojca Świętego w Krakowie. W pierwszej części analizy przedstawiłem sytuację w Krakowie przed I pielgrzymką Ojca Świętego, skupiając się na priorytetach antykościelnych działań władz w dekadzie lat siedemdziesiątych ubiegłego stulecia. Następnie omówiłem sposób przygotowania i plany władz związane z wizytą polskiego papieża, jej przebieg, a także przedstawiłem oceny pielgrzymki i efekty dla Kościoła, partyjnych dygnitarzy oraz społeczeństwa.

Wniosek, jaki się nasuwa w związku z przeprowadzoną przeze mnie analiza, to potwierdzenie, iż władze komunistyczne przywiązywały bardzo dużą wagę do właściwego $\mathrm{z}$ ich punktu widzenia przebiegu pielgrzymki. $Z$ drugiej strony, nie potrafiły docenić efektu, jaki przyniosła wizyta Ojca Świętego, nie tylko dla mieszkańców Krakowa, ale również dla wszystkich Polaków - świadczą o tym zarówno dokumenty aparatu represji, jak i struktur partyjno-państwowych.

Słowa kluczowe: Jan Paweł II, Kościół, władze, Episkopat Polski, Kraków, KK PZPR, SB

\section{WPROWADZENIE}

Truizmem jest stwierdzenie, że I pielgrzymka Ojca Świętego do Ojczyzny przyniosła znaczące efekty dla odrodzenia polskiej wspólnoty. Jak trafnie podkreślał Andrzej Nowak: ,,[...] efekty nauki Jana Pawła II z wi- 
zyty w PRL przyszły szybko, a Polacy na nowo uwierzyli, że mogą stanowić wspólnotę"1 ${ }^{11}$ Wielu historyków właśnie w wizycie Jana Pawła II widzi jedno z najistotniejszych źródeł rewolucji „Solidarności”"2 i trudno, myślę, odmówić im w tym względzie znacznej dozy słuszności.

Celem analizy, jaką chcę $\mathrm{w}$ tym miejscu podjąć, jest dokładne i możliwie całościowe spojrzenie na krakowski etap pierwszej wizyty Jana Pawła II w Ojczyźnie z perspektywy władz PRL. W toku swoich rozważań przedstawię stan wiedzy na ten temat oraz nakreślę wnioski dotyczące przygotowań do wizyty, jej przebiegu i efektów pielgrzymki. Mimo że powstało już kilka znaczących publikacji poświęconych wizycie Jana Pawła II w Polsce w 1979 r. ${ }^{3}$, ciągle brakuje całościowego spojrzenia na pielgrzymkę polskiego papieża do Krakowa oraz wpisania jej w szerszą problematykę relacji państwo-Kościół w PRL w końcowym okresie dekady lat siedemdziesiątych ubiegłego stulecia ${ }^{4}$.

${ }^{1}$ A. Nowak, Kościót na straży polskiej wolności, t. 4: Czas walki z Bogiem, Kraków 2011, s. 152.

${ }^{2}$ A. Dudek, R. Gryz, Komuniści i Kościót w Polsce (1945-1989), Kraków 2006, s. 346-347; J. Żaryn, Jan Pawet II pogromca żelaznej kurtyny, w: Solidarność z Błoń. Wokół nauczania społecznego Jana Pawła II, red. M. Drzonek, M. Siedziako, Szczecin 2011, s. 20-21; R. Łatka, Stosunki państwo-Kościół w latach osiemdziesiatych na przykładzie wizyt Jana Pawła II w Krakowie, w: Stosunki państwo-Kościót w Polsce 1944-2010. Studia i materiaty, red. R. Łatka, Kraków 2012, s. 96-97.

${ }^{3} \mathrm{Na}$ temat I pielgrzymki powstało już kilka samodzielnych, wartych uwagi opracowań historycznych: Wizyta Jana Pawła II w Polsce 1979. Dokumenty KC PZPR i MSW, oprac. A. Friszke, M. Zaremba, Warszawa 2005; M. Lasota, Zabezpieczenie pobytu Jana Pawła II w Polsce, w: Operacja: zniszczyć Kościót, red. F. Musiał, J. Szarek, Kraków 2007, s. 135-159; W.J. Skalski, Pierwsza pielgrzymka Ojca Świętego Jana Pawła II do Polski. Jan Paweł II w Nowym Targu - 8 czerwca 1979 r. w dokumentach Stużby Bezpieczeństwa PRL, Kraków 2008; F. Musiał, Operacja "Lato-79". Zadania Stużby Bezpieczeństwa w czasie pierwszej pielgrzymki Jana Pawła II do Polski, "Zeszyty Historyczne WiN-u” 2012, 35, s. 219-228. Problematyka ta pojawiała się również rzecz jasna w syntezach poświęconych relacjom państwo-Kościół w PRL: J. Żaryn, Dzieje Kościoła katolickiego w Polsce (1945-1989), Warszawa 2003, s. 405-414; A. Dudek, R. Gryz, op. cit., s. 341-347; Z. Zieliński, S. Bober, Kościót w Polsce 1944-2007, Poznań 2009, s. 201-207. Problematykę tej wizyty poruszałem również w kilku własnych publikacjach: R. Łatka, Stosunki państwo-Kościót, s. 93-105; idem, Pielgrzymki Jana Pawła II do Krakowa w oczach SB. Wybór dokumentów, oprac. R. Łatka, Kraków 2013, s. 11-15, 33-73; idem, Polityka władz Polski ",ludowej" wobec Kościoła katolickiego w latach 1944-1979 (przypadek krakowski), „Zeszyty Historyczne WiN-u” 2014, 39, s. 184-187; idem, Najważniejsi funkcjonariusze SB w czasie wizyt papieskich w Krakowie, w: Elity komunistyczne w Polsce, red. M. Szumiło, T. Żukowski, Warszawa 2015 [w druku]; idem, Polityka władz PRL wobec Kościoła katolickiego w województwie krakowskim w latach 1975-1980, w: PRL na pochylni 1975-1980, red. D. Iwaneczko, Rzeszów 2016 [w druku]. Warto sięgnąć również po fragmenty popularnego opracowania Marka Lasoty, Donos na Wojtyłę. Karol Wojtyła w teczkach bezpieki, Kraków 2006, s. 279-316.

${ }^{4} \mathrm{Na}$ temat polityki wyznaniowej władz PRL w latach siedemdziesiątych zob. szerzej: 
Najważniejszym elementem mojej analizy będzie przedstawienie charakteru polityki władz wobec Kościoła w odniesieniu do wizyty Jana Pawła II w Krakowie. Zwrócę szczególną uwagę na działania o charakterze represyjnym i dezintegracyjnym, jakie podejmowano przed i w czasie pielgrzymki. Zanim jednak przejdę do zasadniczego tematu mojego tekstu, przedstawiona zostanie sytuacja w Krakowie przed pierwszą wizyta Ojca Świętego, gdzie skupiłem się na prezentacji priorytetów antykościelnych działań władz w dekadzie lat siedemdziesiątych. Następnie w sposób syntetyczny omówię negocjacje dotyczące trasy i programu pielgrzymki ${ }^{5}$. Kolejnym etapem mojej analizy będzie przedstawienie przygotowań i planów władz związanych z wizytą oraz przebiegu pielgrzymki w Krakowie. W końcowej części omówię oceny pielgrzymki oraz podsumuję jej efekty dla Kościoła i reżimu komunistycznego w Polsce.

\section{SYTUACJA PRZED I PIELGRZYMKA JANA PAWŁA II DO OJCZYZNY}

Nowy okres w polityce rządu wobec Kościoła otwiera objęcie przez Edwarda Gierka funkcji I sekretarza KC PZPR w konsekwencji rewolty robotniczej na Wybrzeżu. Wraz ze zmianami, jakie nastąpiły na szczytach władzy w PRL, dokonano pewnych zmian w polityce wyznaniowej. Pierwszy sygnał o zmianie nastawienia rządzących do Kościoła pojawił się przy okazji exposé premiera nowego rządu 23 grudnia 1970 r. Piotr Jaroszewicz powiedział:

\footnotetext{
K. Pawlicka, Polityka władz wobec Kościoła katolickiego (grudzień 1970 - październik 1978), Warszawa 2004; K. Maniewska, Kościół katolicki w Bydgoszczy wobec prób laicyzacji i dezintegracji społeczeństwa w okresie rzadów Edwarda Gierka (1970-1980), Warszawa 2007; J. Żaryn, Stosunki państwo-Kościót katolicki w latach siedemdziesiatych XX w., w: „Oaza wolności”. Duszpasterstwa akademickie w latach siedemdziesiatych XX w., red. M. Marcinkiewicz, Szczecin 2011, s. 11-19; R. Gryz, Między liberalizacją a dezintegracją. Stosunki państwo-Kościół w latach siedemdziesiatych, w: Stosunki państwo-Kościót, s. 73-92; J. Nowak, „Zwalczać wroga aktywność kleru..." - antykościelna działalność Departamentu IV MSW na przykładzie lat osiemdziesiatych ze szczególnym uwzględnieniem województwa krakowskiego, "Arcana” 2014, 2, s. 104-131. Zob. również, Plany pracy Departamentu IV MSW na lata 1972-1979, oprac. M. Biełaszko, A. Piekarska, P. Tomasik, C. Wilanowski, Warszawa 2007. Por. z dokumentacją UdsW z tego okresu, A. Friszke, PRL wobec Kościoła. Akta 1970-1978, Warszawa 2010.

${ }^{5}$ Nie ma potrzeby w tym miejscu omawiania przebiegu owych negocjacji, gdyż zostały one już przedstawione dość szczegółowo w literaturze przedmiotu. Zob. szerzej: A. Friszke, M. Zaremba, Wokót pierwszej pielgrzymki, w: Wizyta Jana Pawła II, s. 38-43; A. Dudek, R. Gryz, op. cit., s. 344-346; M. Lasota, Donos na Wojtyte, s. 281-283; R. Łatka, Stosunki państwo-Kościót, s. 94; idem, Wstęp, [do:] Pielgrzymki Jana Pawła II do Krakowa, s. 11-14.
} 
Dążąc do umocnienia w ramach Frontu Jedności Narodu współdziałania wszystkich obywateli wierzących i niewierzących, zmierzać będziemy do pełnej normalizacji stosunków między państwem a Kościołem, oczekując zarazem, że wysiłki rządu spotkają się z właściwym zrozumieniem w duchownych i świeckich środowiskach katolickich ${ }^{6}$.

Odejście od polityki poprzedników, kryjące się za postulatem „normalizacji”, było jednak częściowe, a priorytety władz zbytnio się nie zmieniły. Nie zamierzano rezygnować z takich działań, jak aktywność Urzędu do spraw Wyznań [dalej: UdsW], ograniczenia w budownictwie sakralnym czy powrót religii z kaplic do szkół7. Drugim z najważniejszych argumentów za jedynie stwarzaniem pozorów zmian $\mathrm{w}$ polityce władz wobec Kościoła była mentalność funkcjonariuszy partyjnych, która przecież nie mogła się istotnie zmienić $\mathrm{z}$ dnia na dzień. Świadczą o tym również Plany Pracy Departamentu IV Ministerstwa Spraw Wewnętrznych [dalej: MSW], odpowiadającego za kontrolę nad Kościołem katolickim. W jednym z nich możemy przeczytać, że wśród celów tej struktury było m.in.: ,,$\ldots]$ rozpoznawać wyprzedzająco szkodliwą politycznie, ideologicznie i społecznie działalność hierarchii [...] Kościołów rzymskokatolickiego [i innych] rozwijać działania dezintegracyjne i operacyjne ${ }^{\prime \prime}$. Tego typu cele pojawiały się $\mathrm{w}$ dokumentacji MSW również w kolejnych latach dekady lat siedemdziesiątych ${ }^{10}$. W dalszym ciągu jednym z zasadniczych celów struktur partyjno-państwowych było skłócenie duchowieństwa, a przede wszystkim prymasa Stefana Wyszyńskiego i kard. Karola Wojtyły. W tym celu śledzono każdy ruch metropolity krakowskiego i doszukiwano się w jego wypowiedziach ewentualnych pól konfliktu z kard. Wyszyńskim ${ }^{11}$. Metropolita krakowski został otoczony agenturą i była

6 „Trybuna Ludu” 24 XII 1970. Kilka dni później 29 grudnia Rada Główna Episkopatu odniosła się pozytywnie do tych słów. Jak opisuje to Jan Żaryn: „W końcu postanowiono, że Kościół będzie otwarty na rozmowy z władzą w tym nie będzie powstrzymywać Stolicy Apostolskiej i rządu PRL w poszukiwaniu zbliżenia stanowisk", J. Żaryn, Dzieje Kościoła, s. 294.

${ }^{7}$ Zob. szerzej: APK 29/2382/640 KK PZPR Wydział Pracy Ideowo-Wychowawczej. Instrukcje, wytyczne i pisma okólne KC PZPR 1975-1977, k. 363-373, Niektóre problemy stosunków pomiędzy państwem a Kościołem, II 1976.

${ }^{8}$ K. Pawlicka, op. cit., s. 40-49; R. Gryz, op. cit., s. 73-92.

${ }^{9}$ Informacja na temat oceny działalności Kościoła katolickiego, stowarzyszeń i organizacji katolickich oraz innych wyznań objętych pracą operacyjną Departamentu IV, w: Plany pracy Departamentu IV MSW, s. 2-13.

${ }^{10}$ Plany pracy Departamentu IV MSW.

${ }^{11}$ Również agentura umieszczona w otoczeniu kard. Wyszyńskiego miała za zadanie wyłapywać wszelkie pola sporów i ewentualne krytyczne słowa prymasa wobec metropolity krakowskiego. Na ten temat zob. szerzej: W stużbie Boga i Polski. Komunistyczna bezpieka wobec kardynała Stefana Wyszyńskiego, wybór, wstęp, oprac. J. Marecki, P. Nitecki, R. Szczypta-Szczęch, Kraków 2014. 
ona dość skuteczna w pozyskiwaniu informacji dotyczących przyszłego papieża ${ }^{12}$.

Kolejnym istotnym problemem, jaki pojawił się w polityce władz PRL wobec Kościoła w latach siedemdziesiątych było powstanie w 1976 r. zorganizowanej opozycji i jej stosunek do duchowieństwa ${ }^{13}$. Szczególną trudnością dla władz była postawa kard. Wojtyły, który nie krył swojej sympatii dla strajkujących robotników i nowo tworzących się organizacji ${ }^{14}$. Celem, jaki stawiały sobie UdsW i SB było przecinanie wszelkich kontaktów opozycji z duchowieństwem, a przede wszystkim z hierarchią kościelną. Władze miały świadomość groźnych skutków tego rodzaju współpracy. W związku z tym wykazywano dużą aktywność w zwalczaniu kapłanów zaangażowanych w działania na rzecz rodzącej się opozycji. Analizowano również stosunek Kościoła do poszczególnych odłamów opozycji, zauważając dystans hierarchii kościelnej do KOR-u i grup z nim związanych $^{15}$. W Krakowie śledzono również związki duchowieństwa z orga-

${ }^{12}$ Do najważniejszych OZI w otoczeniu kard. Wojtyły należeli: TW o ps. „Jurek", „Delta", „Marek”, „Trybun”, „Karol”, M. Lasota, Między Krakowem, a Rzymem, w: Operacja: zniszczyć Kościót, s. 117. Najgroźniejszym i najlepiej poinformowanym informatorem SB był TW „Leon” (który występował również pod pseudonimami „Zbyszek” i „Karol”). Zob. szerzej: IPN Kr 009/9975, t. 1-12: Teczka personalna i teczka pracy TW „Leon”/ "Zbyszek”/ „Karol”. Warto dodać, iż na temat jego działalności agenturalnej powstała obszerna książka, K. Brodacki, Trzy twarze Juliana Haraschina, Kraków 2015. Do realizacji zadań dezintegracyjnych w 1973 r. powołano nową centralną strukturę tzw. Grupę „D”. Jednym z najbardziej brutalnych przejawów jej działania w Krakowie w okresie lat siedemdziesiątych było pobicie ks. Andrzeja Bardeckiego w 1977 r. Zob. szerzej: F. Musiał, „Zakres pracy ... bez zmian". Wydział IV SB w Krakowie 1975-1978, w: idem, Raj grabarzy narodu. Studia i materiaty do dziejów aparatu represji w Polsce ",ludowej" 1945-1989, Kraków 2010, s. 301. Na temat działań Grupy „D” zob. szerzej: M. Lasota, O raporcie sejmowej komisji poświęconej Samodzielnej Grupie „D” w MSW, „Biuletyn Instytutu Pamięci Narodowej” 2003, 1, s. 37-56; idem, Informacja o działalności komórek "D” pionu IV byłej Stużby Bezpieczeństwa, ibidem, s. 29-37.

${ }^{13} \mathrm{Na}$ temat opozycji wobec władz komunistycznych w latach 1976-1980 zob. szerzej: A. Friszke, Opozycja polityczna w PRL 1945-1980, Londyn 1994, s. 339-591; Co nam zostało z tych lat... Opozycja polityczna 1976-1980 z dzisiejszej perspektywy, red. J. Eisler, Warszawa 2003; T. Gąsowski, „Niestychanie pożyteczni szaleńcy”. Przedsierpniowi opozycjoniści w poszukiwaniu formuly realistycznego działania, w: Realizm polityczny, red. R. Łatka, „Politeja” 2013, 25, s. 147-158. Nie powstała jeszcze żadna całościowa publikacja dotycząca stosunku Kościoła do opozycji z lat 1976-1980, luki tej nie wypełnia z pewnością praca: A. Anusz, Kościót katolicki wobec opozycji politycznej w Polsce w latach 1976-1980, Warszawa 2001.

${ }^{14}$ Informacja sporządzona przez funkcjonariuszy Wydziału IV SB KW MO w Krakowie dotycząca realizacji akcji „Lato-76”, Kraków 1976, w: Ku prawdzie i wolności. Komunistyczna bezpieka wobec kard. Karola Wojtyty, wybór, wstęp, oprac. J. Marecki, M. Lasota, R. Szczęch, Kraków 2009, s. 565-572. Kardynał Wojtyła ponadto spotykał się z osobami należącymi do szeroko pojętej opozycji przedsierpniowej.

${ }^{15}$ ANK 29/2382/385 KK PZPR w Krakowie, Kancelaria I sekretarza, Informacje dotyczące działalności antysocjalistycznej KOR, ROPCIO i inne 1976-1980, k. 519. 
nizacjami o zasięgu regionalnym. Można w tym miejscu wymienić Studencki Komitet Solidarności i powstałe w późniejszym okresie inicjatywy, takie jak Instytut Katyński czy Chrześcijańska Wspólnota Ludzi Pracy ${ }^{16}$. Jak pisano w jednej z analiz SB: „Metropolita krakowski z uwaga śledzi działalność grup dysydenckich i w pełni ją akceptuje. $Z$ taktycznych tylko względów unika oficjalnego włączenia Kościoła do tej działalności"17. Okres lat 1976-1978 to, jak oceniał Marek Lasota, czas coraz większej bezradności aparatu represji, a w konsekwencji władz w stosunku do działań kard. Wojtyły ${ }^{18}$.

Polityki władz wobec Kościoła nie zmienił również wybór Karola Wojtyły na papieża 16 października 1978 r. $^{19}$. Dygnitarze partyjni przez dość długi czas mieli problemy z dostrzeżeniem konsekwencji wyboru kardynałów. Dominowały szok i niedowierzanie. Na posiedzeniu Komitetu Centralnego padła teza, którą ochoczo podchwycono, że „Ostatecznie lepszy Wojtyła jako papież tam niż jako prymas tutaj” ${ }^{20}$. Nie tylko nie udało się propagandowo zdyskontować wyboru Karola Wojtyły na papieża, ale również musiano pójść na nieplanowane ustępstwa. Wśród najbardziej istotnych była rezygnacja z uzgodnionego wcześniej trybu mianowania biskupów, zwanego zasadą terno, w stosunku do następcy Jana Pawła II w archidiecezji krakowskiej. Ks. Franciszek Macharski został metropolitą krakowskim pod koniec 1978 r. z pominięciem tej zasady. Mimo że władze twierdziły, iż jest to jednorazowe ustępstwo, miało się okazać inaczej przy kolejnych nominacjach ${ }^{21}$.

Kolejny istotny problem dla władz pojawił się bardzo szybko, bowiem Episkopat Polski i sam papież zaczęli wspominać o możliwości pielgrzymki Ojca Świętego do kraju. Po raz pierwszy publicznie kwestia ta została podniesiona przez kard. Stefana Wyszyńskiego już w niecały miesiąc po konklawe - 6 listopada 1978 r., gdy stwierdził on:

Jest nadzieja na to, że Ojciec Święty chce jak najprędzej przybyć do Polski. Najlepszą sposobnością są uroczystości świętego Stanisława w Krakowie, zapowiedziane na 13 maja przyszłego roku. Może przy tej okazji Ojciec Święty zobaczy nie tylko Kraków

${ }^{16}$ Zob. Opozycja małopolska w dokumentach 1976-1980, oprac. A. Roliński, Kraków 2003.

${ }^{17}$ Cyt. za: M. Lasota, Donos na Wojtyłe, s. 262. Zob. szerzej: F. Musiał, „Zakres pracy... bez zmian", s. 298.

${ }^{18}$ M. Lasota, Działania operacyjne UB-SB przeciwko kard. Karolowi Wojtyle, w: Ku prawdzie i wolności, s. 26; idem, Donos na Wojtyłę, s. 264-265.

${ }^{19}$ A. Dudek, R. Gryz, op. cit., s. 340-344; R. Gryz, op. cit., s. 88-89.

${ }^{20}$ K. Kąkol, Spowiedź pogromcy Kościoła, Olsztyn 1994, s. 90; A. Dudek, Ślady Peerelu, Kraków 2005, s. 141-142.

${ }^{21}$ A. Dudek, R. Gryz, op. cit., s. 343; R. Łatka, Polityka władz PRL wobec Kościoła katolickiego w województwie krakowskim w latach 1980-1989, Kraków 2016. 
i Częstochowę. Ale pozwólcie, że jako człowiek dyskretny zamknę usta i nie pozwolę mówić memu sercu, a powierzę te myśli waszym sercom. Co wymodlicie, to będzie zyskiem Kościoła w Polsce i w Rzymie 22 .

Pod koniec zaś tego miesiąca została jasno zakomunikowana w Komunikacie z posiedzenia Konferencji Episkopatu Polski. Wobec takiego obrotu sprawy władze stawiały opór, nie chcąc działać pod presją faktów dokonanych. W czasie rozmowy z Sekretarzem Episkopatu bp. Bronisławem Dąbrowskim Stanisław Kania powiedział, że o wizycie Jana Pawła II w PRL nie może być mowy. Dopiero w czasie spotkania prymasa Wyszyńskiego z Edwardem Gierkiem 24 stycznia 1979 r. ten drugi oświadczył, że Ojciec Święty ma prawo przybyć do kraju²3. Władze starały się jednak uzyskać najbardziej optymalny dla siebie termin i warunki ${ }^{24}$.

\section{PLANY, CELE, PRZYGOTOWANIA}

W czasie negocjacji dotyczących pielgrzymki papieża do Polski oczywiste się stało, że odwiedzi on swoją dawną diecezję. Do przyjazdu Jana Pawła II władze wojewódzkie przygotowywały się bardzo intensywnie i na wielu poziomach. Zadania przydzielono organom PZPR, administracji (głównie UdsW i jego terenowym strukturom), a przede wszystkim SB. Sporządzano obszerne plany i analizy dotyczące przygotowań Kościoła do wizyty i jej skutków dla systemu PRL-owskiego ${ }^{25}$. Było to związane przede wszystkim z negatywną oceną skutków wyboru Jana Pawła II i zagrożeń, jakie może przynieść wizyta. Bronisław Michaliszyn, jeden z najważniejszych oficerów MO w województwie, oceniał je w następujący sposób:

Wybór kard. Wojtyły na papieża wywołał w niektórych kręgach kościelnych i grup antysocjalistycznych atmosferę podekscytowania i euforii. Wpłynął również na zacieśnienie spoistości wewnętrznej kleru, usztywnienie postaw politycznych duchowieństwa oraz niektórych świeckich działaczy katolickich, a także na śmiałość formułowania krytycznych, często wrogich poglądów. Na tym tle przewidywana wizyta papieża w Krakowie

${ }^{22}$ Cyt. za: R. Łatka, Wstęp, s. 12.

${ }^{23}$ Jak warto podkreślić, decyzję o zgodzie władz na przyjazd Jana Pawła II do PRL E. Gierek podjął wbrew stanowisku L. Breżniewa, A. Dudek, Ślady Peerelu, s. 144-145; A. Friszke, M. Zaremba, Wokót pierwszej pielgrzymki, s. 36-38.

${ }^{24}$ Główny cel, czyli ominięcie majowego terminu na rocznicę śmierci św. Stanisława, udało się osiagnnąć, ale termin przesunięto o jedynie 3 tygodnie, co i tak poczytywano sobie za duży sukces. APK 29/2382/435 KK PZPR Wydz. Organizacyjny. Informacje bieżące o sytuacji politycznej i gospodarczej w woj. miejskim krakowskim, Informacja bieżąca z 5 III 1979, k. 203; A. Friszke, M. Zaremba, Wokót pierwszej pielgrzymki, s. 33-36.

${ }^{25}$ F. Musiał, Operacja "Lato-79", s. 219-228. 
związana z 900 rocznicą śmierci S. Sczepanowskiego ma specyficzny wydźwięk. Sytuacja wymaga odpowiedniego przygotowania sił i środków i wypracowania zasad taktycznego działania w przypadkach ewentualnych zadziałań grup antysocjalistycznych, które chciałyby przy tej okazji wystąpić publicznie ${ }^{26}$.

Komunistyczne władze do prawidłowego przebiegu przygotowań do wizyty przywiązywały znaczną wagę. Jak trafnie zauważył Filip Musiał: „,Starano się stworzyć scenariusz działań, który pozwoliłby komunistom jak najmniej boleśnie przejść przez zbliżające się wydarzenia"27, ponadto:

Celem władz państwowych jest zdyskontowanie wizyty dla umocnienia jedności moralno-politycznej narodu i jego konsolidowanie wokół budownictwa socjalistycznego w Polsce. Można to osiągnąć tylko wówczas, jeżeli nie dopuścimy do wykorzystania wizyty przeciwko władzy ludowej i zapewnimy jej przebieg zgodnie z ustalonym programem $^{28}$.

Zgodnie z założeniami PRL-owskich dygnitarzy zadania związane $\mathrm{z}$ wizytą miały iść $w$ dwóch głównych kierunkach: osłabienia negatywnych dla władz konsekwencji pielgrzymki oraz propagandowego wykorzystania atmosfery pielgrzymki dla poprawienia notowań reżimu na arenie międzynarodowej ${ }^{29}$. W wypadku tej drugiej grupy zagadnień zakładano m.in. przygotowanie materiałów przeznaczonych dla dziennikarzy zagranicznych ukazujących dorobek „35-lecia Polski Ludowej” oraz zorganizowanie dla nich atrakcji turystycznych i kulturalnych. Ponadto planowano np., że „miejscowości, w których papież będzie przebywał należy udekorować flagami i szturmówkami o barwach narodowych, transparentami i hasłami dotyczącymi 35-lecia PRL, 40-lecia napaści hitlerowskiej na Polskę i wybuchu II wojny światowej, wychowania narodów dla pokoju, jedności Polaków itp." ${ }^{\prime 30}$.

Priorytetowym zadaniem stawianym przed organizacją partyjna, UdsW i SB było zdobywanie informacji na temat wszystkiego, co było

${ }^{26}$ AIPN Kr 552/101 KW MO w Krakowie Wydział WSK - Materiały na posiedzenie kierownictwa 2 II 1979 - 10 VIII 1979, k. 190-191, wystąpienie naczelnika woj. Stanowiska Kierowania KW MO w Krakowie ppłk. Bronisława Michaliszyna [brak daty], Kraków.

${ }^{27}$ F. Musiał, Operacja „Lato-79”, s. 220. Por. Wytyczne kierownika Sztabu MSW w sprawie zadań jednostek resortu spraw wewnętrznych związanych z operacją ,"Lato-79", 24 IV, Warszawa, w: Pielgrzymki Jana Pawła II do Krakowa, s. 33-36.

${ }^{28}$ IPN Kr 038/3 t. 6, WUSW w Nowym Sączu Sprawa Obiektowa „Lato-79”, k. 9.

${ }^{29}$ R. Łatka, Wstęp, s. 14; F. Musiał, Operacja "Lato-79", s. 221-222.

${ }^{30}$ Notatka ze spotkania Stanisława Kani z I sekretarzami wybranych Komitetów Wojewódzkich PZPR dnia 22 marca 1979 roku, w: Wizyta Jana Pawta II w Polsce, s. 181; F. Musiał, Operacja "Lato-79”, s. 221. 
związanie z wizytą ${ }^{31}$. Drugim nie mniej istotnym celem SB było zapobieganie kontaktom opozycji z Kościołem, ponieważ owa współpraca mogła zaowocować groźnymi dla monopolu władzy PZPR konsekwencjami. W tym celu zbierano informacje na temat opinii, komentarzy, przygotowań i działań różnych środowisk ${ }^{32}$. W związku z wizytą Jana Pawła II utworzono różnorodne zespoły odpowiadające za przygotowanie pielgrzymki. Sukcesem biskupów było stworzenie wspólnego zespołu państwowo-kościelnego, który miał odpowiadać za ustalenie szczegółów organizacyjnych wizyty. Z ramienia władz w jego skład wchodzili: Stanisław Kania, Józef Czyrek, Kazimierz Kąkol minister - kierownik UdsW i Aleksander Merker (dyrektor generalny tej instytucji). Kościół reprezentowali: abp Franciszek Macharski, bp Bronisław Dąbrowski i ks. Alojzy Orszulik. Pierwsze jej spotkanie miało miejsce 14 lutego 1979 r. To właśnie na forum komisji ustalano ostatecznie przebieg wizyty i jej program ${ }^{33}$. Zespół miał również swoje odpowiedniki w terenie. Ustalanie dokładnego przebiegu pielgrzymki Jana Pawła II w Krakowie nie odbywało się bez utrudnień ze strony władz, które wszelkimi sposobami chciały ograniczyć kontakt Ojca Świętego z wiernymi. Negocjacje, jakie toczył abp Franciszek Macharski i jego przedstawiciele z władzami województwa, niejednokrotnie były dość uciążliwe i skomplikowane. Mnożono niedogodności m.in. z zapewnieniem dnia wolnego od pracy, kosztami uroczystości czy tak przyziemnymi kwestiami, jak lokalizacja podium na nabożeństwo z udziałem papieża. Szczególnie problematyczny dla kurii krakowskiej okazał się jednak nie krakowski etap uroczystości, ale negocjacje dotyczące wizyty Ojca Świętego w Nowym Targu ${ }^{34}$.

Poza wspólnym zespołem zarówno władze partyjno-państwowe, jak i Kościół utworzyły własne zespoły przygotowujące wizytę $e^{35}$. W archidiecezji krakowskiej władze kościelne powołały w kwietniu 1979 r. Kościelny Komitet Organizacyjny składający się z 17 osób, którego zadaniem było opracowanie programu pobytu Jana Pawła II w Krakowie. Jak odnotował aparat represji:

${ }^{31}$ ANK 29/2382/395 KK PZPR Kancelaria I sekretarza - Informacje dotyczące przygotowań i przebiegu wizyty w Polsce Jana Pawła II /Kraków/ 6-10 VI 1979.

${ }^{32}$ AIPN Kr 060/79 Sprawa Obiektowa „Lato-79”, t. 3, k. 16-21, 23, Plan działań operacyjno-profilaktycznych wydziału III KW MO w Krakowie w okresie operacji „Lato-79” z 5 V 1979. Szerzej nt. planów - zob. R. Łatka, Stosunki państwo-Kościót, s. 93-96.

${ }^{33}$ M. Lasota, Donos na Wojtyłe, s. 281-283; A. Friszke, M. Zaremba, op. cit., s. 38-39; A. Dudek, R. Gryz, op. cit., s. 345-346.

${ }^{34}$ Zob. szerzej: W.J. Skalski, op. cit., s. 22.

${ }^{35}$ A. Friszke, M. Zaremba, op. cit., s. 44. 
Kierownictwo Kurii Krakowskiej podjęło aktywne przygotowania do przyjęcia papieża. Wysiłki hierarchów krakowskich zmierzają między innymi do:

- nadania wizycie papieża w Krakowie charakteru masowego o skali dotychczas niespotykanej,

- wykazani[a] - na forum krajowym i międzynarodowym siły i zwartości Kościoła,

- wzmożeni[a] ofensywy ideologicznej i politycznej, w celu wzmocnienia pozycji społecznej Kościoła i przygotowani[a] do uzyskania przez niego warunków do uzyskania przez niego odpowiedniego statusu publiczno-prawnego,

- sprawnego przebiegu zaplanowanych imprez religijnych z udziałem Ojca św. i zapewnieni[a] mu bezpieczeństwa ${ }^{36}$.

Zgodnie z poleceniami czołowych dygnitarzy partyjnych w każdym województwie (w tym również w woj. krakowskim), w którym miał przebywać papież, utworzono sztaby wojewódzkie pod przewodnictwem I sekretarzy KW PZPR, złożone z najważniejszych dygnitarzy partyjno-państwowych, podległe poleceniom $\mathrm{z}$ centrali ${ }^{37}$. Miały one za zadanie:

- zapewnić sprawny przebieg wizyty papieża oraz uzyskać maksymalne efekty dla socjalistycznego państwa, ograniczając jednocześnie do minimum skutki negatywne;

- dołożyć na wszystkich szczeblach starań, żeby wizyta była dobrze przygotowana i przebiegała w korzystnym klimacie również w zakresie stosunków między państwem i kościołem [sic!]. W tym celu nie należy dopuszczać do powstawania zadrażnień we wzajemnych stosunkach;

$[\ldots]$

- przeciwstawić się tendencjom maksymalistycznym strony kościelnej w zakresie frekwencji. W tym celu prowadzić rozmowy z przedstawicielami diecezji, przekonywując i argumentując nasze stanowisko rzeczowymi faktami $[\ldots]^{38}$.

Szczególną rolę do spełnienia miały struktury partyjne w aparacie represji. Zdefiniował je I sekretarz Komitetu Zakładowego PZPR przy KW MO w Krakowie Mieczysław Haberkiewicz, który podkreślał:

Szczególna odpowiedzialność za maksymalną mobilność naszego aparatu, wytwarzanie klimatu i atmosfery do wykorzystania wszystkich sił i możliwości kolektywów pracowniczych spoczywa na członkach i kandydatach Partii [sic!] oraz członkach ZSMP. Od

${ }^{36}$ IPN Kr 08/303 Wydział III, SO „Lato-79”, k. 89, Pismo naczelnika Wydziału IV KW MO w Krakowie Józefa Biela, 26 IV 1979, Kraków. Pierwsze szersze opracowanie na temat sposobu funkcjonowania Kościelnego Komitetu Organizacyjnego w Krakowie miejscowy aparat represji sporządził 3 kwietnia 1979 r., zob. IPN Kr 08/303 Wydział III, SO „Lato-79”, k. 98-100, Pismo naczelnika Wydziału IV KW MO w Krakowie Józefa Biela, 3 IV 1979, Kraków.

${ }^{37}$ A. Friszke, M. Zaremba, op. cit., s. 51.

${ }^{38}$ Notatka ze spotkania Stanisława Kani z I sekretarzami wybranych Komitetów Wojewódzkich PZPR dnia 22 marca 1979, w: Wizyta Jana Pawła II w Polsce 1979, s. 177-178. 
tych towarzyszy oczekujemy i żądać będziemy wzorowej, przykładnej postawy w każdym działaniu i każdej sytuacji. Członkowie i kandydaci Partii [sic!] swoim przykładem wzorowej służby muszą być agitatorami wśród współtowarzyszy pracy ${ }^{39}$.

Najwięcej zadań związanych z „,zabezpieczeniem” wizyty Ojca Świętego otrzymał od władz partyjno-państwowych aparat represji. 15 marca 1979 r. minister spraw wewnętrznych Stanisław Kowalczyk powołał na podstawie dyrektywy PZPR sztab do kierowania akcją zabezpieczania operacyjnego pielgrzymki Jana Pawła II. Działania prowadzono w ramach sprawy operacyjnej krypt. „Lato-79”. Kierował nią gen. Bogusław Stachura, wiceminister spraw wewnętrznych ${ }^{40}$. Utworzono zespoły: rozpoznania i działań operacyjno-politycznych, bezpieczeństwa i porządku publicznego, zaopatrzenia technicznego i regeneracji sił oraz analityczno-informacyjny. Takie same zespoły powołano przy Komendach Wojewódzkich Milicji Obywatelskiej ${ }^{41}$. Całością pracy operacyjnej kierował Departament IV MSW, a w terenie nadzór nad pracą poszczególnych zespołów

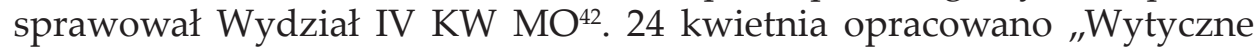
kierownika Sztabu MSW” w sprawie zadań jednostek resortu, związanych z ,zabezpieczaniem pielgrzymki”. Najważniejszym zadaniem aparatu represji było: „Rozwijanie działań operacyjno-rozpoznawczych i profilaktyczno-neutralizacyjnych wobec grup i środowisk kontrolowanych przez SB i $\mathrm{MO}^{\prime \prime 4}$. Szczególne zagrożenie aparat represji widział w związku Jana Pawła II z archidiecezją krakowską i możliwością uczynienia z niej wzorca dla innych jednostek organizacyjnych Kościoła ${ }^{44}$.

${ }^{39}$ IPN Kr 08/303 Wydział III, SO „Lato-79”, k. 16, Plan pracy partyjno-politycznej wśród funkcjonariuszy MO i SB miejskiego województwa krakowskiego na okres operacji „Lato-79”, 5 V 1979, Kraków.

${ }^{40}$ F. Musiał, Operacja „Lato-79", s. 222; R. Łatka, Wstęp, s. 13-14.

${ }^{41}$ IPN Kr 08/303 SO krypt. „Lato-79”, k. 14-15, Decyzja Kierownika Sztabu KWMO w Krakowie w sprawie wyznaczenia zespołów roboczych do opracowania planów kierowania zabezpieczeniem poszczególnych operacji w ramach operacji „Lato-79”.

${ }^{42}$ R. Łatka, Wstęp, s. 14. Por. A. Namysło, T. Kurpierz, "Jestem od Pana Janika", "Biuletyn Instytutu Pamięci Narodowej” 2002, 7, s. 43; G. Majchrzak, Operacja „Lato-79”, "Biuletyn Instytutu Pamięci Narodowej" 2002, 7, s. 52.30 kwietnia z kolei sporządzono szczegółowy harmonogram działania krakowskiego sztabu, w którym określano kolejne etapy operacji „Lato-79” w województwie krakowskim, IPN Kr 08/303 SO krypt. „Lato-79”, k. 12-13, Harmonogram posiedzeń Sztabu KW MO w Krakowie związanych z pracami zabezpieczenia operacji „Lato-79”, 30 IV 1979, Kraków.

${ }^{43}$ Wytyczne kierownika Sztabu MSW w sprawie zadań jednostek resortu spraw wewnętrznych związanych z operacją „Lato-79”, 24 IV 1979, Warszawa, w: Pielgrzymki Jana Pawła II do Krakowa, s. 33. W analogiczny sposób zadania aparatu represji definiował naczelnik antykościelnych struktur aparatu represji w Krakowie Józef Biel, IPN Kr 08/303 Wydział III, SO „Lato-79”, k. 90, Pismo naczelnika Wydziału IV KW MO w Krakowie Józefa Biela, 26 IV 1979, Kraków.

${ }^{44}$ R. Łatka, Wstęp, s. 14. Por. M. Lasota, Zabezpieczenie pobytu Jana Pawła II, s. 139-140. 
Główne zadania rozpoznawcze i prewencyjne koncentrowały się na środowiskach opozycyjnych, a także na rozpoznaniu ,zamierzeń i inicjatyw hierarchii, kleru i aktywu kościelnego" ${ }^{\prime 4}$. Kierunki działań aparatu represji wobec "środowisk antysocjalistycznych" w Krakowie obrazuje „Plan działań operacyjno-profilaktycznych Wydziału III KW MO"46. Spodziewano się, że w środowiskach opozycyjnych wizyta papieża wywoła "szczególną atmosferę podekscytowania i emocji”. Liczono się także z tym, że "figuranci" będą ją chcieli wykorzystać do "zademonstrowania swojej obecności i poszerzenia sfery wpływów". Z tego powodu polecono: „Uaktywnienie pracy operacyjnej ze wszystkimi posiadanymi źródłami informacji wywodzącymi się ze środowisk kontrolowanych przez Wydział III, celem zapewnienia dopływu wyprzedzających informacji" 47 .

Najważniejszym spośród planów opracowanych przez krakowską SB był „Plan operacyjnych działań do sprawy obiektowej krypt. »Lato-79«", opracowany przez naczelnika Wydziału IV. Koncentrowano się na działaniach operacyjnych mających na celu:

- rozpoznanie zakresu przygotowań Kościoła krakowskiego do wizyty papieża,

- maksymalne ograniczenie jej politycznego charakteru,

- operacyjne zabezpieczenie jej przebiegu,

- odpowiednie polityczne i operacyjne zdyskontowanie wizyty ${ }^{48}$.

Do każdej sfery działań przydzielono agenturę, której wyznaczono określone zadania zgodnie z kategoriami, do jakich przydzielono poszczególne osobowe źródła informacji ${ }^{49}$. Wśród najbardziej istotnych zadań wymieniano:

- rozeznanie głównych kierunków i koncepcji polityki wschodniej Watykanu w stosunku do PRL (ze szczególnym uwzględnieniem zmian, jakie wprowadza nowy papież w związku ze znajomością realiów);

${ }^{45}$ IPN Kr 08/303 Wydział III, SO „Lato-79”, k. 90-91, Pismo naczelnika Wydziału IV KW MO w Krakowie Józefa Biela, 26 IV 1979, Kraków; F. Musiał, Operacja „Lato-79”, s. 223-224.

${ }^{46}$ Plan działań operacyjno-profilaktycznych Wydziału III KW MO w Krakowie w okresie Operacji „Lato-79”, 5 V 1979, Kraków, w: Pielgrzymki Jana Pawła II do Krakowa, s. $38-41$.

${ }^{47}$ Ibidem, s. 40.

${ }^{48}$ Plan operacyjnych działań do sprawy obiektowej krypt. „Lato-79”, nr rej. 21742, w: Pielgrzymki Jana Pawła II do Krakowa, s. 48; M. Lasota, Zabezpieczenie pobytu Jana Pawła II, s. $141-142$.

${ }^{49}$ Agenturę podzielono na 8 kategorii. Najważniejsi agenci SB mieli, jak to określano: ,[...] dotarcie do Jana Pawła II bądź członków towarzyszącej mu delegacji watykańskiej”. Zob. szerzej M. Lasota, Donos na Wojtyłe, s. 296-297. 
- rozeznanie rzeczywistych stosunków Jana Pawła II i St. Wyszyńskiego, niezależnie od publicznych gestów ${ }^{50}$.

\section{Jak trafnie podkreślał Filip Musiał:}

Obok wymienionych działań informacyjnych realizowano całą gamę przedsięwzięć o charakterze inspiracyjno-manipulacyjnym. Przez sieć agenturalną starano się wpływać np. [na - dop. red.] zachowanie środowisk opozycyjnych. Głównym elementem tajnej inspiracji realizowanej przez tzw. agenturę wpływu stawały się próby przekonywania do odstąpienia przez opozycjonistów - w trosce o religijny wymiar pielgrzymki - od akcentów natury politycznej. Gdy tego rodzaju próby wpływu okazywały się nieskuteczne, podejmowano mniej wysublimowane działania - konfiskowano ulotki, plakaty, publikacje bezdebitowe, które część środowisk opozycyjnych miała zamiar kolportować w czasie uroczystości z udziałem papieża ${ }^{51}$.

Szczególną uwagę koncentrowano na ulotkach w językach obcych, informujących o aktywności opozycji ${ }^{52}$. Ponadto struktury zajmujące się opozycją w innych województwach miały nie dopuścić do przyjazdu na uroczystości z udziałem papieża "figurantów" z rejonów ich działania ${ }^{53}$. Pod równie ścisłą kontrolą znajdowały się środowiska młodzieżowe, a szczególnie duszpasterstwa akademickie i oazy ${ }^{54}$. Zgodnie z jednym z planów operacyjnych SB zakładano „,realizowanie kombinacji operacyjnych rozszerzających możliwości operacyjne tw. Poprzez umiejscowienie ich w kręgach osób wymagających szczególnej kontroli operacyjnej lub wśród organizatorów imprez związanych z przyjazdem papieża"55.

Te działania uzupełniały zadania przekazane do realizacji innym wydziałom krakowskiej SB. Wśród nich najważniejsze były działania Wydziału II, odpowiadającego za kontrolę operacyjną nad cudzoziemcami oraz zadania powierzone do realizacji pionom pomocniczym aparatu represji ${ }^{56}$.

${ }^{50}$ M. Lasota, Donos na Wojtyte, s. 296-297.

${ }^{51}$ F. Musiał, Operacja "Lato-79”, s. 225. Por. M. Lasota, Zabezpieczenie pobytu Jana Pawła II, s. 152-154. Por. W.J. Skalski, op. cit., s. 32-44.

${ }^{52}$ F. Musiał, Operacja "Lato-79", s. 225

${ }^{53}$ IPN Kr 08/303 Wydział III, SO „Lato-79”, k. 84-85, Pismo naczelnika Wydziału III KW MO w Krakowie Jana Billa do wszystkich województw oraz do Wydz. KW MO: III, III-1, 22 V 1979, Kraków. Pismo to było pokłosiem informacji przesyłanych z innych województw, w których ostrzegano, iż opozycjoniści z innych regionów kraju planują przybyć na uroczystości w Krakowie. Zob. np.: IPN Kr 08/303 Wydział III, SO „Lato-79”, k. 88, Pismo naczelnika Wydziału III KW MO w Poznaniu z 17 V 1979. Równie bliska była współpraca Wydziałów IV z poszczególnych województw. Zob.: szerzej W.J. Skalski, op. cit., s. 50-51.

${ }^{54}$ K. Jarkiewicz, Duszpasterstwa akademickie Krakowa po II wojnie światowej, Kraków 2004, s. 405-416.

${ }^{55}$ M. Lasota, Donos na Wojtyłe, s. 303.

${ }^{56}$ R. Łatka, Wstęp, s. 14. Por. W.J. Skalski, op. cit., s. 59-62. 
Aparat represji podejmował wiele działań mających na celu zmniejszenie frekwencji $\mathrm{w}$ czasie poszczególnych uroczystości z udziałem papieża ${ }^{57}$. W ten sposób starano się zmniejszyć potencjalne grono odbiorców papieskiego przesłania. Jednym z uciążliwych utrudnień były te związane z uzyskaniem zwolnienia z pracy czy szkoły na czas uroczystości z udziałem Jana Pawła II. Niemniej jednak tego typu działania władz nie tylko nie okazały się skuteczne, ale wywoływały również frustrację i chęć sprzeciwienia się władzom, co w efekcie masowo nastąpiło ${ }^{58}$.

Pod czujną kontrolą aparatu represji znajdowały się również dekoracje budynków przygotowane $z$ okazji wizyty Jana Pawła II. Jak wynika z licznych dokumentów krakowskiej SB, na wielu z nich pojawiły się różnego rodzaju dekoracje - od choragiewek przez flagi w barwach Polski oraz Watykanu, aż po flagi o „,wrogiej treści”. Ze szczególną uwagą potraktowano Miasteczko Studenckie. Jak wynikało z raportu Adama Wypaska, funkcjonariusza Wydziału IV, kilka domów studenckich było wyjątkowo bogato udekorowanych. Autor notatki wspominał o DS przy ulicy Piastowskiej nr IV i V oraz dwóch akademikach przy ul. Dzierżyńskiego (obecnie Juliusza Lea) nr 98 i $100^{59}$.

Warto zwrócić uwagę również na charakter propagandy prasowej w organie prasowym KK PZPR w okresie przed wizytą papieską. Podkreślenia wymaga fakt, że o samej pielgrzymce zaczęto pisać dopiero $\mathrm{w}$ momencie ogłoszenia oficjalnego zaproszenia władz państwowych ${ }^{60}$. Potem zaś zamieszczano jedynie krótkie notki PAP i przedruki z "Trybuny Ludu" - przykładowo tekst Mariana Kuszewskiego Stosunki państwo-Kościót przez pryzmat interesu Polski, w którym autor zwracał uwage na kruchość relacji wzajemnych oraz na wartość dialogu w tychże relacjach ${ }^{61}$. A zatem I pielgrzymka Jana Pawła II do Ojczyzny miała, w przeciwieństwie do dwóch kolejnych wizyt, charakter marginalny ${ }^{62}$.

${ }^{57}$ W.J. Skalski, op. cit., s. 63-71.

${ }^{58}$ Załącznik do Informacji o działaniach ideowo-wychowawczych z 15 maja 1979 r., rozesłanej do Komitetów Wojewódzkich PZPR, w: Wizyta Jana Pawła II w Polsce 1979, s. 218-219.

${ }^{59}$ IPN Kr 08/303 Wydział III, SO „Lato-79”, k. 235-236, Notatka służbowa z przeprowadzonej lustracji w rejonie miasteczka studenckiego, 3 VI 1979, Kraków.

60 "Gazeta Południowa", rocznik 1979.

${ }^{61}$ M. Kuszewski, Stosunki państwo-Kościót przez pryzmat interesu Polski, "Gazeta Południowa" 24 V 1979.

${ }^{62}$ Zob. szerzej: R. Łatka, Propaganda władz PRL wobec II wizyty Jana Pawła II na przykładzie Gazety Krakowskiej, „Komunizm. System - Ludzie - Dokumentacja” 2013, 2, s. 95-107; idem, Polityka władz PRL. 


\section{PRZEBIEG KRAKOWSKIEGO ETAPU WIZYTY, PAPIESKIE PRZESŁANIE}

Jan Paweł II przybył do Krakowa 6 czerwca i od początku swojego pobytu w rodzinnej archidiecezji był szczególnie inwigilowany przez aparat represji. Operacja zabezpieczania pierwszej wizyty była największą w historii aparatu represji w PRL. Zorganizowano do niej olbrzymią ilość sił i środków, w samym tylko Krakowie zaangażowano ponad 67 tys. funkcjonariuszy MO i SB oraz 480 tajnych współpracowników aparatu bezpieczeństwa $^{63}$. Z pewnością wywiązała się ona z funkcji informacyjnej, czego dowodem są zachowane liczne materiały archiwalne. Każda uroczystość w czasie pielgrzymki była ściśle monitorowana i kontrolowana nie tylko przez aparat represji, ale również za pomocą źródeł agenturalnych:

Wszystkie osobowe źródła informacji uczestniczące w masowych imprezach w dniach pobytu papieża w Krakowie otrzymają zadania, aby w tych imprezach brać udział łącznie z kontrolowanymi grupami i osobami oraz czynnego przeciwdziałania wszelkim szkodliwym inicjatywom z nich wypływających, mogących przynieść szkody polityczno-operacyjne $^{64}$.

Jedną z najważniejszych operacji aparatu represji w czasie pierwszej wizyty było obserwowanie pobytu Jana Pawła II w siedzibie kurii przy ul. Franciszkańskiej 3. Nosiła ona kryptonim „Rezydencja”, a o jej skali świadczy fakt, że zaangażowanych w nią było 120 pracowników operacyjnych, 82 funkcjonariuszy MO oraz kilkunastu pracowników Wydziału "B", zajmującego się m.in. podsłuchami ${ }^{65}$.

Pozyskiwano informacje na temat przebiegu wizyty ze wszystkich środowisk krakowskich, zarówno opozycyjnych, jak i kościelnych ${ }^{66}$. Przykładem może być Informacja Wydziału III krakowskiej SB, która odnotowała wiele komentarzy na temat wizyty Ojca Świętego w środowisku naukowym:

${ }^{63}$ R. Terlecki, Miecz i tarcza komunizmu. Historia Aparatu Bezpieczeństwa w Polsce 19441990, Kraków 2007, s. 246.

${ }^{64}$ M. Lasota, Donos na Wojtyte, s. 304.

${ }^{65}$ AIPN Kr 08/262, t. 3: Plan fizycznego zabezpieczenia operacji krypt. „Rezydencja” w dniach 6-9 VI 1979, k. 116-117; ibidem, t. 2: Wykaz pracowników zabezpieczających operację krypt. „Rezydencja”, k. 14-16 [brak daty]. Zob. szerzej: M. Komaniecka, Pod obserwacja i na podstuchu. Rzeczowe środki pracy operacyjnej aparatu bezpieczeństwa w województwie krakowskim w latach 1945-1990, Kraków 2014, s. 249-250. Podobne działania aparat represji podejmował również w czasie wizyty w Nowym Targu. Zob. szerzej: W. Skalski, op. cit.

${ }^{66}$ Wydział III krakowskiej SB sporządzał codziennie informacje na temat środowisk opozycyjnych. Zob. szerzej: IPN Kr 08/303 Wydział III, SO „Lato-79”. 
W wąskich grupach naukowców, głównie z UJ wskazywano, że wizyta papieża jest demonstracją Kościoła wymierzoną w stronę władz państwowych. Niektórzy z dyskutantów stwierdzali, że papież chętnie nawiązałby współpracę z władzami PRL pod warunkiem, że te zgodziłyby się na pewne ustępstwa w zakresie budownictwa sakralnego, zwiększonego nakładu czasopism katolickich, dostępu do środków masowego przekazu, oddziaływania na środowisko akademickie itp. Takie stanowisko Kościoła zostało przez niektórych pracowników nauki odczytane jako przebiegłe pociągnięcie dla wytworzenia w społeczeństwie przekonania, iż to właśnie władze PRL stawiają przeszkody w normalizacji stosunków państwo-Kościół. Podkreślano, że podczas swoich wystąpień papież poprzez akcentowanie patriotyzmu i jedności narodu zjednał sobie sympatię nie tylko praktykujących katolików ${ }^{67}$.

W swoim przywitalnym przemówieniu na Błoniach Jan Paweł II podkreślił bardzo wyraźnie swój silny związek z Krakowem. Uczynił to w prostych, ale jednocześnie pięknych słowach, które myślę warto przytoczyć: „,Kraków od najmłodszych lat mojego życia, od lat dziecięcych jeszcze, był dla mnie szczególną syntezą wszystkiego, co polskie i co chrześcijańskie. Zawsze mówił mi o wielkiej przeszłości mojej Ojczyzny. Zawsze najpełniej wyrażał jej dzieje" ${ }^{68}$ oraz ze wzruszeniem dodał, że „Tak bardzo czuję was - czuję was poprzez to oddalenie, do którego wezwał mnie Pan"69.

Istotne znaczenie miały odniesienia do duszpasterskiego powodu wizyty -900. rocznicy śmierci św. Stanisława, które były trzonem zasadniczego przesłania Ojca Świętego. Ponadto Jan Paweł II podsumował w swoim wystąpieniu w Katedrze Wawelskiej siedmioletni okres trwania Synodu Archidiecezji Krakowskiej - obchodów ku czci św. Stanisława, dodając w końcowej części swojej wypowiedzi: „Nigdy nie przypuszczałem, że w zakończeniu prac synodu wypadnie mi uczestniczyć $\mathrm{w}$ charakterze... gościa z Rzymu"70.

Analizując przebieg wizyty Ojca Świętego w Krakowie, nie można również nie wspomnieć o nabożeństwie dla młodzieży zorganizowanym

${ }^{67}$ IPN Kr 060/79 t. 3, k. 158, Informacja z Wydziału III-1, VI 1979.

${ }^{68}$ Jan Paweł II, Przemówienie powitalne na Błoniach, Kraków 6 VI 1979, w: Jan Paweł II. Pielgrzymki do Ojczyzny 1979, 1983, 1987, 1991, 1995, 1997, 1999, 2002. Przemówienia, homilie, Kraków 2012, s. 143. Analogiczne odniesienia Ojciec Święty zawarł również w swoim kolejnym przemówieniu, zob. szerzej: Słowo do księży i wiernych archidiecezji krakowskiej zgromadzonych w katedrze, Kraków 6 VI 1979, w: ibidem, s. 146.

${ }^{69}$ Jan Paweł II, Przemówienie powitalne na Błoniach, Kraków 6 VI 1979, w: Jan Paweł II. Pielgrzymki do Ojczyzny, s. 143. Swoją silną więź z Krakowem, a zwłaszcza ze światem akademickim Ojciec Święty podkreślił również w homilii wygłoszonej do świata nauki i kultury w kościele na Skałce, Jan Paweł II, Przemówienie do przedstawicieli nauki i kultury zgromadzonych w kościele oo. Paulinów na Skałce, w: ibidem, s. 166-171. Zob. także: F. Ziejka, Jan Pawet II i polski świat akademicki, Kraków 2014.

${ }^{70}$ Jan Paweł II, Homilia w czasie Mszy św. odprawionej w katedrze z okazji zakończenia Synodu Archidiecezji Krakowskiej, w: Jan Paweł II. Pielgrzymki do Ojczyzny, s. 163-164. 
na Skałce. Do chwili obecnej nie znamy ostatecznej przyczyny, z jakiej Jan Paweł II odstąpił od wcześniej przygotowanego przemówienia w czasie spotkania z młodzieżą akademicką na Skałce. Można przypuszczać, że obawiał się, iż wygłoszenie ostrzejszego w tonie przemówienia może wpłynąć na i tak bardzo już napiętą atmosferę i skłonić młodzież do demonstracji ${ }^{11}$. W swoim przemówieniu Ojciec Święty wyraźnie podkreślił swój silny związek z Duszpasterstwem Akademickim oraz zwrócił uwagę, że tym, co jest najważniejsze w działalności tego środowiska, jest przygotowanie młodej polskiej inteligencji do życia w małżeństwie i rodzinie chrześcijańskiej:

Muszę wam powiedzieć, że te dwie, szczególnie przeze mnie umiłowane dziedziny duszpasterstwa, duszpasterstwo młodzieży i duszpasterstwo małżeństw, czyli rodzin zawsze stanowiły jakąś całość, jedno wynikało z drugiego, nieraz nawet mówiłem duszpasterzom akademickim: tak dobrze, że w ramach waszych konferencji podejmujecie różne tematy, ale najwięcej uczynicie, jeżeli młodych ludzi, przyszłą polską inteligencję, przygotujecie do życia w małżeństwie i w rodzinie chrześcijańskiej. Niech to wystarczy. Mogę wam najwyżej powiedzieć, że będę się starał w Rzymie, i gdziekolwiek mnie losy z tej racji zaprowadza, być wierny ideałom duszpasterstwa akademickiego w Krakowie i w Polsce ${ }^{72}$.

Nawiązał również do działalności Sacrosongów, podkreślając, że:

Ukształtowana w taki sposób wartość kulturalna jest świadectwem autentycznego życia duchowego. Świadczy o tym, że treści chrześcijańskie nadal posiadają swe rzeczywiste prawo obywatelstwa w duszach twórców. Owszem, że są właściwie niezastąpione jako źródło inspiracji. Sacrosong mówi rok po roku o społecznym zasięgu tych inspiracji w Polsce ${ }^{73}$.

Słowa Jana Pawła II spowodowały, że nastrój napięcia zmienił się w zadumę, a po zakończeniu uroczystości, zgodnie z życzeniem Ojca Świętego, młodzież spokojnie rozeszła się do domów ${ }^{74}$.

${ }^{71}$ G. Weigel, Świadek nadziei. Biografia Papieża Jana Pawła II, Kraków 2012, s. 401-402.

${ }^{72}$ Jan Paweł II, Przemówienie do młodzieży zgromadzonej przed kościołem oo. Paulinów na Skałce, Kraków 8 VI 1979, w: Jan Pawet II. Pielgrzymki do Ojczyzny, s. 173-174.

${ }^{73}$ Ibidem, s. 172-175. Jak trafnie podkreślał Bogusław Tracz, rozwój działalności kulturalnej w Kościele intensywnie następował od początku lat siedemdziesiątych, a kard. Wojtyła był zdecydowanym zwolennikiem jej rozwijania, idem, Karol Wojtyła - Jan Pawet II i kultura niezależna, w: Solidarność z Błoń, s. 17-24. Warto podkreślić, iż działania Kościoła w tym względzie znajdowały się pod czujną kontrolą aparatu represji. Zob. szerzej: Sprawa dot. "sacrosongów” prowadzona przez Wydz. IV KWMO Kraków AIPN Kr IPN Kr 039/102, Materiały dot. śledztw, konfliktów, sanktuariów, sacrosongów, katechizacji w latach 1971-1980. Zob. również: K. Jarkiewicz, op. cit., s. 271-291, 369-379; R. Łatka, Polityka władz PRL wobec Kościoła katolickiego w województwie krakowskim w latach 1975-1980. Najpełniej związek Kościoła z kulturą uwidocznił się w czasie stanu wojennego, gdy świątynie stały się miejscem, w którym artyści masowo prezentowali swoją twórczość. Na ten temat zob. szerzej: Kościót i kultura niezależna, red. B. Tracz, Katowice 2011.

${ }^{74}$ G. Weigel, op. cit., s. 401-402. 
Istotne znaczenie, szczególnie dla mieszkańców Nowej Huty, miało nabożeństwo w opactwie Cystersów w Mogile. Władze nie zgodziły się na odwiedzenie przez Ojca Świętego kościoła w Bieńczycach, którego poświęcenia dokonał jeszcze jako kardynał. W swojej homilii przypomniał on trudne dzieje budowy wspomnianej świątyni oraz walkę o kościół w Mistrzejowicach (wspomniał bohaterskiego ks. Józefa Kurzeję ${ }^{75}$, który idei budowy tej świątyni poświęcił własne życie). Dodał ponadto, że budowa kościoła to dopiero pierwszy etap, za którym powinno pójść wypełnienie życia Ewangelią76. Mocno podkreślił również, że "Chrystus nie zgodzi się nigdy z tym, aby człowiek był uznawany - albo sam siebie za takiego uznawał - tylko za narzędzie produkcji; żeby tylko według tego był oceniany, mierzony, wartościowany. Chrystus nigdy się z tym nie zgodzi"77.

W czasie homilii na Błoniach ${ }^{78}$ Jan Paweł II stwierdził wyraźnie, że celem ludzkiego życia jest „,świat Boga”, zaś „Powołanie to wymaga, by żyć w wewnętrznej wolności, z pomocą której poszukujemy prawdy i trwamy przy niej z własnego wyboru"79. Najistotniejsze okazało się jednak wezwanie poczynione przez Ojca Świętego pod koniec homilii, gdy wezwał zgromadzonych słowami:

Musicie być mocni, drodzy bracia i siostry! [...] Musicie być mocni mocą wiary! [...] Dziś tej mocy bardziej wam potrzeba, niż w jakiejkolwiek epoce dziejów. Musicie być mocni mocą nadziei, która przynosi pełną radość życia i nie dozwala zasmucać Ducha Świętego! [...] I dlatego [...] proszę was, [...] abyście nigdy nie zwątpili i nie znużyli się, i nie zniechęcili się, [...] abyście mieli ufność [...], abyście szukali zawsze duchowej mocy u Tego, u którego tyle pokoleń ojców naszych i matek ją znajdowało $[\ldots]^{80}$.

Jako swoistą klamrę wizyty należy potraktować słowa, które Ojciec Święty wypowiedział $\mathrm{w}$ czasie pożegnania na krakowskich Balicach: „To wydarzenie bez precedensu było z pewnością aktem odwagi z obu stron, jednakże naszym czasom potrzebny był taki właśnie akt odwagi.

${ }^{75}$ Zob. szerzej: K. Szumal, B. Frydel, Ks. kanonik Józef Kurzeja, Kraków 1998; R. Łatka, Polityka władz PRL wobec Kościoła katolickiego w województwie krakowskim w latach 1975-1980.

${ }^{76}$ Jan Paweł II, Homilia w czasie Mszy św. odprawionej przed opactwem oo. Cystersów w Mogile, Kraków 9 VI 1979, w: Jan Pawet II. Pielgrzymki do Ojczyzny, s. 186-188.

77 Ibidem, s. 189.

${ }^{78} \mathrm{Na}$ Błoniach zgromadziło się ok. miliona wiernych, A. Friszke, M. Zaremba, op. cit., s. 66

${ }^{79}$ Jan Paweł II, Homilia w czasie Mszy św. odprawionej na Błoniach, Kraków 10 VI 1979, w: Jan Pawet II. Pielgrzymki do Ojczyzny, s. 199.

${ }^{80}$ Ibidem, s. 203-204. 
Trzeba czasem się odważyć pójść w tym kierunku, w którym jeszcze nikt nie poszed $\ell^{\prime \prime} 81$.

Mimo podejmowania wielu starań władzom partyjno-państwowym nie udało się w żaden sposób wpłynąć na treść przemówień papieskich ${ }^{82}$. Choć na kilku poziomach starano się wpłynąć na treść wystąpień papieskich, komuniści nie odnieśli w tych staraniach żadnych sukcesów. Bezpieka nie potrafiła również z wyprzedzeniem uzyskać informacji o planowanych wypowiedziach Jana Pawła II. Funkcjonariuszom pozostało jedynie bezradnie je rejestrować, a następnie snuć plany minimalizacji szkód, jakie wyrządzały one reżimowi ${ }^{83}$.

Warto w kilku słowach omówić charakter propagandy władz w czasie wizyty. Organ prasowy KK PZPR w województwie krakowskim - „Gazeta Południowa" pisała o pielgrzymce niezwykle mało ${ }^{84}$. Były to z reguły relacje o charakterze informacyjnym, podkreślające korzystne dla założeń propagandowych władz wątki z przemówień papieskich. Szły one dokładnie po linii wytycznych opracowanych w KC PZPR, które mówiły, że w czasie pielgrzymki nie zamierzano „prowadzić odrębnej ideowo-wychowawczej i politycznej kampanii poświęconej wyłącznie wizycie papieża i polityce wyznaniowej partii. Problematykę związaną z naszymi kontaktami z Kościołem i Watykanem przedstawiamy w ramach ogólnonarodowej kampanii związanej z 35-leciem powstania Polski Ludowej i 40 rocznicą napaści Niemiec hitlerowskich na Polskę" ${ }^{\prime 85}$.

\section{OCENY WIZYTY, PODSUMOWANIE}

Postawa władz w czasie pierwszej pielgrzymki Jana Pawła II była niejednorodna. Z jednej bowiem strony, starano się utrzymywać oficjalne poprawne kontakty z Kościołem ${ }^{86}$, z drugiej zaś, intensywność działań SB

${ }^{81}$ Jan Paweł II, Przemówienie pożegnalne na lotnisku w Balicach, Kraków 10 VI 1979, w: Jan Paweł II. Pielgrzymki do Ojczyzny, s. 208. Zob. także: Jan Paweł II, Musicie od siebie wymagać, Poznań 1984, s. 222.

${ }^{82}$ Szczegółowo tego typu starania przedstawili: A. Friszke, M. Zaremba, op. cit., s. 55-69.

${ }^{83}$ A. Friszke, M. Zaremba, op. cit., s. 55-58, 64-65; F. Musiał, Operacja „Lato-79”, s. 226.

84 "Gazeta Południowa", rocznik 1979.

${ }^{85}$ Materiał Wydziału Pracy Ideowo-Wychowawczej KC PZPR rozesłany zapewne do Komitetów Wojewódzkich PZPR, w: Wizyta Jana Pawła II w Polsce 1979, s. 220.

${ }^{86}$ Świadczą o tym spotkania przedstawicieli władz z abp. Macharskim i kanclerzem kurii krakowskiej Bronisławem Fidelusem. Notatka ze spotkania metropolity krakowskiego z prezydentem Krakowa zob.: AIPN KR 08/262 SO krypt. „Lato-79”, t. 7, k. 8-10, Relacja ze spotkania dyrektora Wydziału ds. Wyznań Józefa Duśki z ks. Fidelusem, zob. ibidem, k. 14-15. 
była bardzo wysoka ${ }^{87}$. Aparat represji posiadał dokładne informacje na temat przygotowań i planów Kościoła. Jak odnotowano w sprawozdaniu z realizacji zadań związanych z pielgrzymką Jana Pawła II:

Zorganizowane przez Wydział IV pełne i wyprzedzające rozpoznanie koncepcji i zamierzeń organizacyjnych Kurii metropolitalnej, zakonów i świeckiego aktywu katolickiego, umożliwiało podejmowanie skutecznych działań polityczno-operacyjnych i inspiracyjnych.

Właściwe rozpoznanie politycznych, programowych i organizacyjnych zamierzeń Kościoła stanowiło też podstawę do przekazania wyprzedzających informacji do instancji partyjnej, Departamentu IV MSW oraz podejmowania właściwych decyzji oraz prawidłowego ukierunkowania osobowych źródeł informacji ${ }^{88}$.

Najtrudniej z dzisiejszej perspektywy ocenić efekt działań manipulacyjnych. Faktem pozostaje, jak trafnie podkreślał Filip Musiał, że w czasie pielgrzymki nie doszło do buntu społecznego, manifestacji ani szczególnie wzmożonych działań opozycji ${ }^{89}$. Tego typu ocenę należy rozciągnąć na sytuację w całym kraju ${ }^{90}$. Na ile było to efektem skutecznej działalności agentury wpływu, a na ile zabiegów biskupów, trudno z perspektywy dnia dzisiejszego ocenić, szczególnie że część materiałów partyjno-państwowych oraz przede wszystkim aparatu represji została wybrakowana. Niezależnie jednak od prawdziwych przyczyn aparat represji potraktował to jako swój sukces ${ }^{91}$. Znaczącym sukcesem operacyjnym był fakt wprowadzenia przez bezpiekę agentury ze środowisk kościelnych do wszystkich kościelnych komitetów organizacyjnych oraz posiadanie osobowych źródeł informacji w bezpośrednim otoczeniu Jana Pawła II ${ }^{92}$. W założeniu ta

\footnotetext{
${ }^{87}$ R. Łatka, Wstęp, s. 14-15.
}

${ }^{88}$ IPN Kr 060/79 SO krypt. „Lato-79”, k. 148, Sprawozdanie z realizacji zadań przez KW MO Kraków w ramach operacji „Lato-79”, 14 VI 1979; M. Lasota, Zabezpieczenie pobytu Jana Pawła II, s. 156-159.

${ }^{89}$ F. Musiał, Operacja „Lato-79”, s. 226.

${ }^{90}$ A. Friszke, M. Zaremba, op. cit., s. 68.

${ }^{91}$ R. Łatka, Wstęp, s. 15.

${ }^{92}$ Plan operacyjnych działań do sprawy obiektowej krypt. „Lato-79”, nr rej. 21742, w: Pielgrzymki Jana Pawła II do Krakowa, s. 47-70. Wspomniany plan szeroko omówił w swoich publikacjach Marek Lasota: Zabezpieczenie pobytu Jana Pawła II, s. 137-159; Donos na Wojtyłe, s. 293-316. Innym pozytywnym efektem wizyty w ocenie aparatu represji było rozwinięcie współdziałania z krakowskim WdsW, Wydziałem Spraw Wewnętrznych oraz Delegaturą Głównego Urzędu Kontroli Prasy, Publikacji i Widowisk. Jak oceniono: „Efektem tego współdziałania było m.in. wyhamowanie niekorzystnych politycznie inicjatyw Kierownictwa Kurii Krakowskiej, zainspirowanie podjęcia przez czynniki kościelne przedsięwzięć porządkowych, zabezpieczenie religijnego charakteru uroczystości z udziałem papieża”. IPN Kr 060/79 SO krypt. „,Lato-79”, k. 150-151, Sprawozdanie z realizacji zadań przez KW MO Kraków w ramach operacji „Lato-79”, 14 VI 1979. 
sieć konfidentów miała umożliwić wpływ na decyzje podejmowane przez kościelne ośrodki decyzyjne $\mathrm{w}$ trakcie trwania pielgrzymki ${ }^{93}$. Pozyskana wtedy agentura miała istotne znaczenie, jeśli chodzi o kontrolę działalności Kościoła w dekadzie lat osiemdziesiątych ${ }^{94}$. Nie sposób ocenić również jej wpływu na duchownych w archidiecezji krakowskiej, których postawa, jak podkreślano w sprawozdaniu SB, została oceniona przez władze pozytywnie: „Ogólnie zachowanie kleru w czasie wizyty papieża nie nastręczało trudności i było raczej poprawne" ${ }^{\prime 25}$. Wśród duchownych, którzy zachowywali się $\mathrm{w}$ przekonaniu władz negatywnie, wymieniano ${ }^{96}$ znanych z postaw opozycyjnych księży: Józefa Gorzelanego ${ }^{97}$, ks. Mikołaja Kuczkowskiego ${ }^{98}$ oraz duszpasterzy akademickich: o. Zygmunta Tomasza Pawłowskiego ${ }^{99}$ i o. Jana Andrzeja Kłoczowskiego ${ }^{100}$.

Jako porażki SB poczytywała sobie brak zapobiegnięcia kontaktom między zagranicznymi dziennikarzami a redaktorami „Tygodnika Powszechnego" oraz niepowstrzymanie manifestacyjnego przeniesienia poświęconego w kościele na Skałce krzyża i umieszczenie go na terenie Miasteczka Studenckiego ${ }^{101}$. Nie udało się ponadto wytonować aktywności

${ }^{93}$ Jak trafnie wskazuje Filip Musiał nie sposób orzec, na ile miała ona wpływ na sposób funkcjonowania owych komitetów, a szerzej patrząc - na cały krakowski etap pielgrzymki, idem, Operacja "Lato-79", s. 225-226.

${ }^{94} \mathrm{Na}$ ten temat zob. szerzej: R. Łatka, Polityka władz PRL. Wspomnianą agenturę wykorzystywano również w czasie dwóch kolejnych pielgrzymek. Zob. szerzej: Pielgrzymki Jana Pawła II do Krakowa, s. 77-346; R. Łatka, Stużba Bezpieczeństwa wobec III pielgrzymki Jana Pawła II do PRL na przykładzie sytuacji w Krakowie, "Glaukopis” 2014, 31, s. 349-368.

${ }^{95}$ IPN Kr 060/79 SO krypt. „Lato-79”, k. 159, Sprawozdanie z realizacji zadań przez KW MO Kraków w ramach operacji „Lato-79”, 14 VI 1979; M. Lasota, Donos na Wojtyłe, s. 305-306.

96 IPN Kr 060/79 SO krypt. „Lato-79”, k. 159-160, Sprawozdanie z realizacji zadań przez KW MO Kraków w ramach operacji „Lato-79”, 14 VI 1979.

${ }^{97} \mathrm{Na}$ temat ks. Gorzelanego zob. szerzej: K. Wordliczek, Od „Turysty” do "Głaza”: podwójna rola ks. Józefa Gorzelanego, w: Kościót katolicki w czasach komunistycznej dyktatury, t. 2, red. R. Terlecki, J. Szczepaniak, Kraków 2008, s. 249-266.

${ }^{98} \mathrm{Na}$ temat ks. Mikołaja Kuczkowskiego zob. szerzej: K. Bukowski, Zwykli czy niezwykli. Sylwetki osób wspótczesnych, Kraków 1998, s. 257-259; Ku prawdzie i wolności, s. 96; R. Łatka, Polityka władz PRL.

${ }^{99}$ Na temat o. Pawłowskiego zob. szerzej: W. Wiśniewski, Psy Pana Boga. Los Perrros de Dios, Warszawa 2008, s. 105-157; Ku prawdzie i wolności, s. 244-245.

${ }^{100} \mathrm{Na}$ temat o. Kłoczowskiego zob. szerzej: Pielgrzymki Jana Pawła II do Krakowa, s. 46. Zob. także: J.A. Kłoczowski, Kłocz. Autobiografia, rozmawiaja Artur Sporniak i Jan Strzałka, Kraków 2015.

${ }^{101}$ M. Lasota, Donos na Wojtyłe, s. 306-307; R. Łatka, Wstęp, s. 15. Z uwagi na sprzeciw władz krzyża nie umieszczono, tak jak wcześniej planowano na placu przed Domem Studenckim „Akropol”, ale wmurowano przed kościołem na Skałce. Miano przy nim co roku organizować spotkania modlitewne wszystkich studentów zaangażowanych w DA, 
krakowskiego SKS- $\mathrm{u}^{102}$. Jak samokrytycznie pisano we wnioskach sformułowanych w Wydziale III krakowskiej SB dzień po wizycie Ojca Świętego:

1. Pomimo wysiłków kierowanych głównie na uzyskiwanie wyprzedzających informacji nie uzyskano wcześniejszych danych z kręgu DA o zamiarze ustawienia krzyża na Miasteczku Studenckim.

2. Chociaż posiadano wyprzedzającą informację o zamiarach organizowania punktu informacyjnego SKS-u, nie doprowadzono do jego likwidacji, w związku z czym podczas wizyty papieża w Krakowie dziennikarze zachodni prowadzili tam wywiady.

3. Ze względu na ograniczone możliwości tut. Wydziału nie zabezpieczono w dostatecznej mierze kontroli wszystkich osób zaangażowanych w działalność antysocjalistyczną, które przyjechały do Krakowa z terenu kraju ${ }^{103}$.

Z pełnym przekonaniem można jednak stwierdzić, że to nie wspomniane $\mathrm{w}$ dokumentacji aparatu represji przykłady porażek operacyjnych były najważniejsze. Najistotniejszy był sukces przesłania Jana Pawła II. Warto dodać, że przemówienia papieskie zostały przez aparat partyjny i wyznaniowy oraz przez SB przeanalizowane bardzo pobieżnie ${ }^{104}$. Wyciągnięto tylko ogólne wnioski, że miały one szkodliwy z punktu widzenia komunistów charakter, zupełnie zaś nie zastanawiano się nad konsekwencjami papieskich słów. Jak trafnie zauważył Marek Lasota:

Jan Paweł II przyjechał do ojczyzny z głoszoną od dwóch tysięcy lat Dobrą Nowiną. Do jej odczytania i zrozumienia nie trzeba było angażować kilkuset agentów, ponad tysiąca funkcjonariuszy SB i kilkudziesięciu tysięcy funkcjonariuszy MO. Ale zrozumienie tej prostej prawdy okazało się dla komunistycznego reżimu zadaniem dalece przekraczającym jego możliwości ${ }^{105}$.

Mimo tak wielkich nakładów sił i środków pierwsza wizyta Jana Pawła II w PRL okazała się wielkim sukcesem polskiego Kościoła. Porażkę poniosła przede wszystkim propaganda opracowana przez dygnitarzy PZPR, mająca zniechęcać Polaków do udziału w uroczystościach z udzia-

ale z racji nieporozumień co do ich formy i wydarzeń Sierpnia 1980 r. zaniechano ich organizacji, H. Głębocki, Studencki Komitet Solidarności w Krakowie 1977-1980. Zarys działalności, Warszawa 1994, s. 197-198; K. Jarkiewicz, op. cit., s. 415-416.

${ }^{102}$ IPN Kr 060/79 SO krypt. „Lato-79”, k. 146, Sprawozdanie z realizacji zadań przez KW MO Kraków w ramach operacji „Lato-79”, 14 VI 1979; H. Głębocki, op. cit., s. 197-198; R. Łatka, Wstęp, s. 15.

${ }^{103}$ IPN Kr 08/303 Wydział III, SO „,Lato-79”, k. 181, Informacja dot. okresu bezpośrednio poprzedzającego i wizyty papieża w Krakowie, 11 VI 1979, Kraków.

${ }_{104}$ M. Lasota, Donos na Wojtyłe, s. 308-309; W.J. Skalski, op. cit., s. 115; R. Łatka, Wstęp, s. 15.

${ }^{105}$ M. Lasota, Donos na Wojtyłe, s. 310. 
łem papieża. Świadczyły o tym wyraźnie rzesze wiernych uczestniczących w uroczystościach ${ }^{106}$. Po zakończeniu wizyty dało się zaobserwować zdecydowany wzrost pozycji Kościoła w PRL co nabrało szczególnego znaczenia w Sierpniu 1980 r. Władze jednakże zdawały się nie widzieć skali sukcesu Kościoła ${ }^{107}$. Uświadomiły sobie go w pełni dopiero w czasie wydarzeń 1980 r. Jak bowiem trafnie zauważył Jan Żaryn: Jana Pawła II „pielgrzymowanie po Polsce w czerwcu 1979 r. wywołało lawinę pozytywnych skutków, których zwieńczeniem stał się dziesięciomilionowy ruch »Solidarności «"108. Podobną opinię przedstawił Marcin Zaremba, który dodatkowo podkreślał delegitymizację władz komunistycznych:

Rozpoczęta 2 czerwca 1979 r. pielgrzymka Jana Pawła II miała wymiar religijny, ale i społeczny o rewolucyjnych konsekwencjach. W ciągu kilku miesięcy papież stał się narodowym autorytetem, ośrodkiem identyfikacji narodowej. Te uczucia uzewnętrzniły się również podczas jego wizyty [...]. Gdy spotkał się z Edwardem Gierkiem w Belwederze koncentrował na sobie wzrok. Był uśmiechnięty, jednocześnie pełen godności i skupienia. Mówił rzeczy ważne: o polskiej historii, rozumieniu słowa ojczyzna, wspólnocie losu narodu i Kościoła. Wskazując na prawo Polaków do życia w suwerennym państwie, przywracał sens słowom ojczyzna, prawda, wolność. [...] W tej konfrontacji I sekretarz KC PZPR wypadł słabo. Jego przemówienie niczym nie zaskakiwało, było sztampowe i banalne [...]. Gierek był lubiany i szanowany przez niemałą część Polaków. Gdy jednak stanął obok Jana Pawła II i przemówił, stracił całą swoją charyzmę, jego urok przepadł. W procesie delegitymizacji władzy - poprzedzającym każdą rewolucję - było to wydarzenie ważne ${ }^{109}$.

${ }^{106}$ A. Dudek, R. Gryz, op. cit., s. 346-347.

${ }^{107}$ A. Dudek, Prymas Stefan Wyszyński wobec władz komunistycznych w latach 1956-1978, w: Prymas Stefan Kardynat Wyszyński - świadek Ewangelii i tradycji narodowych. Materiaty sesji naukowej w Wyższym Seminarium Duchownym w Kielcach 19 maja 2001 r., red. K. Gurda, T. Gacia, Kielce 2001, s. 51-54.

${ }^{108}$ J. Żaryn, Jan Paweł II pogromca żelaznej kurtyny, s. 21. Ponadto, jak oceniał F. Musiał I pielgrzymka Jana Pawła II do Ojczyzny „Uzmysłowiła milionom wiernych ich siłę, pobudziła na nowo powszechną religijność, ukazała moc wspólnoty. Dla wielu katolików było to pierwsze takie doświadczenie, niektórzy przypomnieli sobie uczucie jedności towarzyszące im kilkanaście lat wcześniej w czasie obchodów Millenium Chrztu Polski. Pojedyncze osoby zobaczyły, że wbrew od dekad sączonej w umysły propagandzie, nie są osamotnione, że miliony innych ludzi także nie mogą oddychać w totalitarnym gorsecie", F. Musiał, Operacja "Lato-79", s. 227.

${ }^{109}$ M. Zaremba, Zimno, ciepło, goraco. Nastroje Polaków od "zimy stulecia” do lata 1980, w: Solidarność od wewnatrz 1980-1981, red. A. Friszke, K. Persak, P. Sowiński, Warszawa 2013, s. 21-22. 


\section{BIBLIOGRAFIA}

\section{Źródła}

Archiwum Instytutu Pamięci Narodowej oddział w Krakowie: 009/9975; 08/262; 08/303; 038/3; 060/79; 552/101.

Archiwum Narodowe w Krakowie, KK PZPR: 29/2382/385; 29/2382/395; 29/2382/435; 29/2382/640.

"Gazeta Południowa", rocznik 1979.

Opozycja małopolska w dokumentach 1976-1980, oprac. A. Roliński, Kraków 2003.

Plany pracy Departamentu IV MSW na lata 1972-1979, oprac. M. Biełaszko, A. Piekarska, P. Tomasik, C. Wilanowski, Warszawa 2007.

Pielgrzymki Jana Pawła II do Krakowa w oczach SB. Wybór dokumentów, oprac. R. Łatka, Kraków 2013.

Wizyta Jana Pawła II w Polsce 1979. Dokumenty KC PZPR i MSW, oprac. A. Friszke, M. Zaremba, Warszawa 2005.

\section{Opracowania}

Anusz A., Kościół katolicki wobec opozycji politycznej w Polsce w latach 1976-1980, Warszawa 2001.

Brodacki K., Trzy twarze Juliana Haraschina, Kraków 2015.

Bukowski K., Zwykli czy niezwykli. Sylwetki osób współczesnych, Kraków 1998.

Co nam zostało z tych lat... Opozycja polityczna 1976-1980 z dzisiejszej perspektywy, red. J. Eisler, Warszawa 2003.

Dudek A., Prymas Stefan Wyszyński wobec władz komunistycznych w latach 1956-1978, w: Prymas Stefan Kardynał Wyszyński - świadek Ewangelii i tradycji narodowych. Materiaty sesji naukowej w Wyższym Seminarium Duchownym w Kielcach 19 maja 2001 r., red. K. Gurda, T. Gacia, Kielce 2001.

Dudek A., Ślady Peerelu, Kraków 2005.

Dudek A., Gryz R., Komuniści i Kościót w Polsce (1945-1989), Kraków 2006.

Friszke A., Opozycja polityczna w PRL 1945-1980, Londyn 1994.

Friszke A., PRL wobec Kościoła. Akta 1970-1978, Warszawa 2010.

Friszke A., Zaremba M., Wokót pierwszej pielgrzymki, w: Wizyta Jana Pawła II w Polsce 1979. Dokumenty KC PZPR i MSW, oprac. A. Friszke, M. Zaremba, Warszawa 2005.

Gąsowski T., "Niestychanie pożyteczni szaleńcy”. Przedsierpniowi opozycjoniści w poszukiwaniu formuty realistycznego działania, w: Realizm polityczny, red. R. Łatka, „Politeja” 2013, 25.

Głębocki H., Studencki Komitet Solidarności w Krakowie 1977-1980. Zarys działalności, Warszawa 1994.

Gryz R., Między liberalizacja a dezintegracją. Stosunki państwo-Kościót w latach siedemdziesiatych, w: Stosunki państwo-Kościót w Polsce 1944-2010. Studia i materiały, red. R. Łatka, Kraków 2012.

Jan Paweł II, Musicie od siebie wymagać, Poznań 1984.

Jan Paweł II. Pielgrzymki do Ojczyzny 1979, 1983, 1987, 1991, 1995, 1997, 1999, 2002. Przemówienia, homilie, Kraków 2012.

Jarkiewicz K., Duszpasterstwa akademickie Krakowa po II wojnie światowej, Kraków 2004.

Kąkol K., Spowiedź pogromcy Kościoła, Olsztyn 1994.

Kłoczowski J.A., Kłocz. Autobiografia, rozmawiaja Artur Sporniak i Jan Strzałka, Kraków 2015.

Komaniecka M., Pod obserwacja i na podstuchu. Rzeczowe środki pracy operacyjnej aparatu bezpieczeństwa w województwie krakowskim w latach 1945-1990, Kraków 2014.

Kościót i kultura niezależna, red. B. Tracz, Katowice 2011. 
Ku prawdzie i wolności. Komunistyczna bezpieka wobec kard. Karola Wojtyły, wybór, wstęp, oprac. J. Marecki, M. Lasota, R. Szczęch, Kraków 2009.

Kuszewski, Stosunki państwo-Kościót przez pryzmat interesu Polski, "Gazeta Południowa" 24 V 1979.

Lasota M., Donos na Wojtyłe. Karol Wojtyła w teczkach bezpieki, Kraków 2006.

Lasota M., Działania operacyjne UB-SB przeciwko kard. Karolowi Wojtyle, w: Ku prawdzie i wolności. Komunistyczna bezpieka wobec kard. Karola Wojtyly, wybór, wstęp, oprac. J. Marecki, M. Lasota, R. Szczęch, Kraków 2009.

Lasota M., Informacja o działalności komórek „D” pionu IV byłej Stużby Bezpieczeństwa, „Biuletyn Instytutu Pamięci Narodowej" 2003, 1.

Lasota M., Między Krakowem, a Rzymem, w: Operacja: zniszczyć Kościót, red. F. Musiał, J. Szarek, Kraków 2007.

Lasota M., O raporcie sejmowej komisji poświęconej Samodzielnej Grupie „D” w MSW, „Biuletyn Instytutu Pamięci Narodowej" 2003, 1.

Lasota M., Zabezpieczenie pobytu Jana Pawła II w Polsce, w: Operacja: zniszczyć Kościót, red. F. Musiał, J. Szarek, Kraków 2007.

Łatka R., Najważniejsi funkcjonariusze SB w czasie wizyt papieskich w Krakowie, w: Elity komunistyczne w Polsce, red. M. Szumiło, T. Żukowski, Warszawa 2015 [w druku].

Łatka R., Polityka władz Polski „ludowej” wobec Kościoła katolickiego w latach 1944-1979 (przypadek krakowski), "Zeszyty Historyczne WiN-u” 2014, 39.

Łatka R., Polityka władz PRL wobec Kościoła katolickiego w województwie krakowskim w latach 1975-1980, w: PRL na pochylni 1975-1980, red. D. Iwaneczko, Rzeszów 2016 [w dru$\mathrm{ku}]$.

Łatka R., Polityka władz PRL wobec Kościoła katolickiego w województwie krakowskim w latach 1980-1989, Kraków 2016.

Łatka R., Propaganda władz PRL wobec II wizyty Jana Pawła II na przykładzie Gazety Krakowskiej, „Komunizm. System - Ludzie - Dokumentacja” 2013, 2.

Łatka R., Stużba Bezpieczeństwa wobec III pielgrzymki Jana Pawła II do PRL na przykładzie sytuacji w Krakowie, "Glaukopis" 2014, 31.

Łatka R., Stosunki państwo-Kościót w latach osiemdziesiatych na przykładzie wizyt Jana Pawta II w Krakowie, w: Stosunki państwo-Kościót w Polsce 1944-2010. Studia i materiały, red. R. Łatka, Kraków 2012.

Łatka R., Wstęp, [do:] Pielgrzymki Jana Pawła II do Krakowa w oczach SB. Wybór dokumentów, oprac. R. Łatka, Kraków 2013.

Majchrzak G., Operacja „Lato-79”, Biuletyn Instytutu Pamięci Narodowej” 2002, 7.

Maniewska K., Kościół katolicki w Bydgoszczy wobec prób laicyzacji i dezintegracji społeczeństwa w okresie rządów Edwarda Gierka (1970-1980), Warszawa 2007.

Musiał F., Operacja "Lato-79". Zadania Stużby Bezpieczeństwa w czasie pierwszej pielgrzymki Jana Pawła II do Polski, "Zeszyty Historyczne WiN-u” 2012, 35.

Musiał F., "Zakres pracy... bez zmian". Wydziat IV SB w Krakowie 1975-1978, w: F. Musiał, Raj grabarzy narodu. Studia i materiały do dziejów aparatu represji w Polsce ",ludowej" 19451989, Kraków 2010.

Namysło A., Kurpierz T., ,Jestem od Pana Janika”, ,Biuletyn Instytutu Pamięci Narodowej” $2002,7$.

Nowak A., Kościót na straży polskiej wolności, t. 4: Czas walki z Bogiem, Kraków 2011.

Nowak J., "Zwalczać wroga aktywność kleru..." - antykościelna działalność Departamentu IV MSW na przykładzie lat osiemdziesiąych ze szczególnym uwzględnieniem województwa krakowskiego, „Arcana” 2014, 2. 
Pawlicka K., Polityka władz wobec Kościoła katolickiego (grudzień 1970 - październik 1978), Warszawa 2004.

Skalski W.J., Pierwsza pielgrzymka Ojca Świętego Jana Pawła II do Polski. Jan Paweł II w Nowym Targu - 8 czerwca 1979 r. w dokumentach Stużby Bezpieczeństwa PRL, Kraków 2008.

Szumal K., Frydel B., Ks. kanonik Józef Kurzeja, Kraków 1998.

Terlecki R., Miecz i tarcza komunizmu. Historia Aparatu Bezpieczeństwa w Polsce 1944-1990, Kraków 2007.

Tracz B., Karol Wojtyła - Jan Paweł II i kultura niezależna, w: Solidarność z Błoń. Wokót nauczania społecznego Jana Pawła II, red. M. Drzonek, M. Siedziako, Szczecin 2011.

Weigel G., Świadek nadziei. Biografia Papieża Jana Pawła II, Kraków 2012.

Wiśniewski W., Psy Pana Boga. Los Perrros de Dios, Warszawa 2008.

Wordliczek K., Od "Turysty” do "Głaza”: podwójna rola ks. Józefa Gorzelanego, w: Kościót katolicki w czasach komunistycznej dyktatury, t. 2, red. R. Terlecki, J. Szczepaniak, Kraków 2008.

W stużbie Boga i Polski. Komunistyczna bezpieka wobec kardynała Stefana Wyszyńskiego, wybór, wstęp, oprac. J. Marecki, P. Nitecki, R. Szczypta-Szczęch, Kraków 2014.

Zaremba M., Zimno, ciepło, goraco. Nastroje Polaków od „zimy stulecia” do lata 1980, w: Solidarność od wewnatrz 1980-1981, red. A. Friszke, K. Persak, P. Sowiński, Warszawa 2013.

Ziejka F., Jan Paweł II i polski świat akademicki, Kraków 2014.

Zieliński Z., Bober S., Kościót w Polsce 1944-2007, Poznań 2009.

Żaryn J., Dzieje Kościoła katolickiego w Polsce (1945-1989), Warszawa 2003.

Żaryn J., Jan Paweł II pogromca żelaznej kurtyny, w: Solidarność z Błoń. Wokół nauczania społecznego Jana Pawła II, red. M. Drzonek, M. Siedziako, Szczecin 2011.

Żaryn J., Stosunki państwo-Kościót katolicki w latach siedemdziesiatych XX w., w: „Oaza wolności". Duszpasterstwa akademickie w latach siedemdziesiątych XX w., red. M. Marcinkiewicz, Szczecin 2011.

\section{ABSTRACT}

The article constitutes an attempt to gain an accurate and holistic view of the Kraków stage of the first visit of John Paul II to his Homeland, especially from the communist authorities' perspective. Special attention has been paid to the nature of the communist authorities' policy towards the Pope's visit in Kraków. In the first part of the analysis, there has been presented the situation in Kraków before the visit of John Paul II, focusing on the priorities of anti-Church activities of the authorities in the decade of the 1970s. Next, there have been discussed the authorities' preparation plans related to the Polish Pope's visit and its course. Moreover, the assessment of the pilgrimage and its effects for the Church, the party dignitaries and society have been presented.

The conclusion which is drawn in connection with conducting the analysis is the confirmation that the communist authorities had attached great importance to the right - from their point of view - course of the pilgrimage. On the other hand, they failed to appreciate the effect which the visit of John Paul II brought not only for the residents of Kraków, but also for all Poles. This is evidenced by the documents of repressive state apparatus and party-state structures.

Key words: John Paul II, Catholic Church, authorities, Episcope, Cracow, PUWP, political police 


\section{NOTA O AUTORZE}

Rafał Łatka - historyk i politolog, dr nauk społecznych z zakresu nauk o polityce (specjalność historia najnowsza Polski). Absolwent Instytutu Nauk Politycznych i Stosunków Międzynarodowych UJ. Autor wielu publikacji naukowych i popularnych, w tym publikacji książkowej Pielgrzymki Jana Pawła II do Krakowa w oczach SB. Wybór dokumentów (Kraków 2012), redaktor tomów studiów: Stosunki państwo-Kościół w Polsce w latach 1944-2010. Studia i materiaty (Kraków 2013) oraz Realizm polityczny (opublikowany w specjalnym numerze pisma „Politeja”, Kraków 2013). Członek redakcji pism: „Glaukopis” „Myśl.PL” oraz portalu Myśl.24.pl. Ekspert Centrum im. Władysława Grabskiego. Współpracownik Instytutu Pamięci Narodowej, Ośrodka Myśli Politycznej oraz portalu promującego historię Histmag.org. Organizator ogólnopolskich konferencji naukowych: „Polskie wizje i oceny komunizmu po 1939 r." (Kraków 2014), „Różne wymiary realizmu politycznego w Polsce »ludowej«" (Kraków 2012), "Stosunki państwo-Kościół w Polsce w latach 1944-2010” (Kraków 2011). Zainteresowania badawcze: historia relacji stosunków państwo-Kościół w PRL, realizm polityczny, komunizm. 